\title{
Zwyczaje żywieniowe osób pracujących w systemie zmianowym a stan ich zdrowia
}

\author{
Agnieszka Momora*, Jan Krupa**
}

Osoby pracujace $w$ systemie zmianowym napotykaja utrudnienia, które uniemożliwiaja im prowadzenie zbilansowanej diety. W związu z powyższym pracownicy zmianowi sa szczególnie narażeni na zwiększone ryzyko chorób takich, jak otyłość, cukrzyca typu 2, choroby wieńcowe, zaburzenia snu i trawienia. Ponadto osoby te maja znacznie pogorszona wydolność psychomotoryczna, co wptywa na ich efektywność w pracy. Celem badania byta analiza nawyków i preferencji żywieniowych osób zatrudnionych w systemie zmianowym. Na podstawie literatury przedstawiona została korelacja między dieta pracowników a ich wydajnościa $i$ efektywnościa w pracy. Ponadto zbadano zależność pomiędzy zachowaniami żywieniowymi badanych a ich stanem zdrowia. Badaniem objęto 79 mieszkańców województwa podkarpackiego. Respondentami byty osoby pracujace w systemie zmianowym. Do przeprowadzenia badania zostat wykorzystany autorski kwestionariusz ankiety, sktadający się z 34 pytań. Dieta respondentów znacznie odbiegała od zasad zdrowego żywienia. W badaniu $32 \%$ pracowników zadeklarowato, że odżywia się zdrowo. Częstotliwość i dtugość odstępów czasowych między positkami byta zależna od charakteru pracy. Podczas zmian dziennych pracownicy odżywiali się regularniej niż noca. Wykazano częste występowanie dolegliwości pokarmowych oraz chorób o podtożu sercowo-naczyniowym.

Słowa kluczowe: praca zmianowa, zachowania żywieniowe, dieta, zdrowie.

Nadesłany: 06.07.18 | Zaakceptowany do druku: 03.12.18

\section{Eating behavior of shift workers and their health condition}

Employees eating irregularly have a significantly reduced psychomotor performance, which affects their work efficiency. Shift workers encounter difficulties that prevent them from having a balanced diet. For this reason, they are particularly exposed to an increased risk of disorders, such as excessive body weight, type 2 diabetes, cardiovascular diseases, sleep and digestion disorders. The aim of the study was to analyze the habits and dietary preferences of shift workers, and to examine the correlation between the eating behaviors of employees and their health condition. Based on a review of the literature the aim of this study was to establish a correlation between employees' nutritional behaviours and their efficiency and effectiveness at work. The study included 79 shift workers, residents of the Podkarpackie Province. The author's questionnaire, consisting of 34 questions, was used to conduct the study. The diet of shift workers differed from the rational principles of nutrition. Regularity of meals was dependent on the nature of the work. During daily shifts, employees were fed more regularly than during the night hours. A high percentage of respondents were employees who consumed

\footnotetext{
* Agnieszka Momora - mgr, Wyższa Szkoła Informatyki i Zarządzania z siedzibą w Rzeszowie.

** Jan Krupa - prof. nadzw. dr hab. inż., Wyższa Szkoła Informatyki i Zarządzania z siedzibą w Rzeszowie. Adres do korespondencji: Wyższa Szkoła Informatyki i Zarządzania z siedzibą w Rzeszowie, ul. Sucharskiego 2,35-225 Rzeszów, e-mail: amomora@wsiz.rzeszow.pl; jkrupa@wsiz.rzeszow.pl.
} 
meals in fast food bars. A high consumption of red meat and highly processed snacks was found. In own research, 32\% of workers declared that they eat healthy. Frequent occurrence of food problems and cardiovascular diseases has been demonstrated. In order to increase the awareness of shift workers, it would be a good undertaking to introduce campaigns and educational programs.

Keywords: shift work, eating behavior, diet, health.

Submitted: 06.07.18 | Accepted: 03.12.18

JEL: I12

\section{Wstęp}

Od drugiej połowy XIX w. liczba osób pracujących na zmiany zaczęła wzrastać. Przełomowym wydarzeniem było wynalezienie w tym czasie żarówki. Od tamtej pory odsetek ten nadal wykazuje tendencję wzrostową (Strajewski i in., 2016). W dzisiejszych czasach najwięcej pracowników zatrudnionych w systemie zmianowym zamieszkuje kraje rozwinięte i rozwijające się. Zgodnie z danymi European Quality of Life Survey (EQLS) szacuje się, że w uprzemysłowionych państwach Europy liczba ta oscyluje w granicach $15-20 \%$, przy czym w takim systemie zdecydowanie częściej pracują mężczyźni. Najwyższy odsetek pracowników zatrudnionych na zmiany, niezależnie od płci, odnotowany został w przedziale wiekowym 25-34 lat (Villosio i in., 2008).

Podejmowanie pracy nocą zaburza rytm dobowy organizmu człowieka. Takie zjawisko może wywoływać wiele nieprawidłowości związanych z okołodobowymi rytmami biologicznymi i czynnościami fizjologicznymi. Skutki pracy zmianowej najczęściej rozpatrywane są w trzech kategoriach. Można wśród nich wyróżnić między innymi konsekwencje o podłożu socjologicznym, biologicznym i zdrowotnym. Według licznych danych literaturowych okazuje się, że stan zdrowia pracowników zmianowych jest istotnie gorszy od stanu zdrowia pracowników systemu dziennego (Ramin i in., 2015). Do najczęściej cytowanych w literaturze skutków zdrowotnych takiego modelu pracy zalicza się m.in. choroby o podłożu sercowo-naczyniowym, niewłaściwą masę ciała, cukrzycę typu 2, a także choroby układu pokarmowego oraz związane z nimi zaburzenia trawienia czy nietolerancje pokarmowe. Wszystkie wymienione schorzenia zaliczone zostały do chorób cywiliza- cyjnych, określanych inaczej chronicznymi, niezakaźnymi chorobami XXI wieku.

Według badań Wołyńca i in. pracownicy mający staż pracy zmianowej krótszy niż 10 lat miewaja przede wszystkim zaburzenia snu, natomiast osoby pracujacce ponad 10 lat częściej zapadają na nadciśnienie tętnicze oraz cukrzycę typu 2 (Wołyniec i in., 2015).

Pawlak i Pawlak podkreślają, że model pracy zmianowej nie powinien być traktowany jako czynnik uniemożliwiający pozostanie w zdrowiu, lecz zwiększający ryzyko niektórych schorzeń (Pawlak i Pawlak, 2015). Jedną ze składowych determinujących osiągnięcie szeroko rozumianego zdrowia jest odpowiedni sposób odżywiania (World Health Organization, 2014).

Osoby pracujace w systemie zmianowym napotykają liczne utrudnienia, uniemożliwiające im kształtowanie pozytywnych nawyków żywieniowych. Nawyki żywieniowe są wypracowanym sposobem doboru produktów żywnościowych. Znaczenie ma także częstotliwość konsumpcji, sposób przyrządzania posiłków i utrwalone rytuały towarzyszące ich spożywaniu.

Van Wormer i in. w 2015 roku opublikowali wyniki badania, którego celem była analiza korelacji pomiędzy czynnikami stylu życia a efektywnością i wydajnością pracowników zmianowych. Zestawione zostały wyniki pracowników, którzy w ciągu 2 lat zwiększyli aktywność fizyczną bądź spożycie warzyw i owoców, z efektami pracowników, u których czynniki stylu życia pozostały stabilne. W pierwszej grupie badanych wykazano mniejszą utratę wydajności i większą efektywność w pracy (Van Wormer, Boucher i Sidebottom, 2015).

Praca na zmiany nocne wiąże się z zaburzeniami rytmu dobowego organizmu, na który składają się: faza czuwania (16 godzin) oraz faza snu (8 godzin). Takie 
zjawisko ściśle koreluje $\mathrm{z}$ wydajnością pracowników zmianowych. Rytm ten jest regulowany przez wiele impulsów ze środowiska (Lemmer i Oster, 2018). Czas snu osób odsypiających w dzień jest zazwyczaj krótszy niż w porze nocnej. Wykazano, że pracownicy zmianowi w porównaniu z pracownikami dziennymi śpią statystycznie o 2 godziny krócej (Bilski, Perz i Perz, 2005). Ponadto sen po powrocie ze zmiany nocnej przypada na najmniej korzystną porę doby, która zwana jest zakazaną strefą (ang. forbiden sleep zone). W tym czasie dochodzi do pogłębiającego się uczucia znużenia i zmęczenia. Ponadto obniża się temperatura ciała i maleje aktywność psychofizyczna. W porze tej wzrasta również subiektywna senność (Lavie, 1997). Zjawisko to zachodzi w okresie nasilającej się biosyntezy melatoniny. Dane kliniczne wskazują, że melatonina pełni funkcje sygnału chronobiologicznego, który informuje organizm o nadejściu czasu snu (Brzęczek, Słonka i Hyla-Klekot, 2016).

Celem artykułu było podjęcie próby określenia nawyków i preferencji żywieniowych osób pracujących w systemie zmianowym. Na podstawie przeglądu literatury przedstawiony został wpływ diety na wydajność i efektywność w pracy. Ponadto zbadano zależność pomiędzy zachowaniami żywieniowymi a stanem zdrowia respondentów. W tym celu dokonano przeglądu błędów żywieniowych, najczęściej popełnianych przez uczestników badania.

\section{Metodyka badań i materiał badawczy}

Podczas realizacji pracy wykorzystano bezpośrednią metode badawcza - ankietyzację. Do przeprowadzenia analizy został użyty autorski kwestionariusz ankiety, składający się z 34 pytań, dotyczących sposobu odżywiania się, pytań ogólnych w zakresie stanu zdrowia oraz metryczki. Ankieta zawierała pytania zamknięte. Biorąc pod uwagę schorzenia, na które są szczególnie narażeni pracownicy zmianowi, takie jak: choroby wieńcowe, nadmierna masa ciała, cukrzyca typu 2 , choroby układu pokarmowego, w tym zaburzenia trawienia i nietolerancje, w pracy zostały omówione wybrane błędy żywieniowe, które istotnie predysponują do ich rozwoju.

Osoby biorące udział w badaniu wykonywały swoją pracę w systemie zmianowym, tj. $6.00-18.00,18.00-6.00$ oraz $6.00-14.00$, 14.00-22.00, 22.00-6.00. Badaniem objęto 79 mieszkańców województwa podkarpackiego. Badanie przeprowadzono w okresie od 1 lutego do 30 kwietnia 2017 roku. Grupę badawczą stanowiły kobiety $(50,6 \%)$ i mężczyźni (49,4\%). Wśród ankietowanych przeważały osoby z grupy wiekowej oscylującej w granicach $26-30$ lat $(31,6 \%)$, natomiast $30,4 \%$ respondentów stanowiły osoby w wieku 31-40 lat. Wiek 20\% respondentów mieścił się w przedziale oscylującym pomiędzy 18-25 lat, zaś najmniej liczna grupe stanowily osoby w wieku $41-50$ lat $(18,4 \%)$.

Ponad połowa ankietowanych $(50,6 \%)$ miała wykształcenie średnie. Wykształcenie wyższe miało $26,6 \%$ respondentów, natomiast pozostała część grupy badawczej $(22,8 \%)$ miała wykształcenie zawodowe. Biorąc pod uwage miejsce zamieszkania respondentów, stwierdzono, że ponad połowa zamieszkiwała tereny wiejskie $(54,4 \%)$. Blisko połowa badanych $(49,4 \%)$ określiła swoją sytuację materialną jako przeciętną. W sytuacji materialnej określonej, jako „dobra” lub „bardzo dobra” znajdowało się $41,7 \%$ pracowników, zaś w trudnej sytuacji materialnej było $8,9 \%$ respondentów.

\section{Wyniki badań}

Wśród respondentów tylko 18,9\% określiło, że interesuje się zdrowym odżywianiem w stopniu wysokim. Najwięcej ankietowanych, bo aż 45,6\%, interesowało się w stopniu średnim, natomiast ponad $10 \%$ respondentów zadeklarowało, że nie przywiązuje wagi do zdrowego odżywiania się. W jednym $\mathrm{z}$ pytań uczestnicy oceniali, czy stosowana przez nich dieta dostarcza wszystkich niezbednych składników odżywczych. Blisko połowa ankietowanych $(49,4 \%)$ uważała swoje odżywianie za wystarczające pod względem ilościowym i jakościowym. Z kolei $1 / 3$ badanych (32\%) zadeklarowała, że stara się odżywiać zdrowo, jednakże nie ma pewności, czy stosowana dieta jest wystarczająco zbilansowana. Najniższy odsetek respondentów $(20,3 \%)$ stanowili pracownicy, którzy ocenili swój sposób odżywiania się jako niewłaściwy, to znaczy taki, który nie dostarcza składników odżywczych w odpowiedniej ilości.

Okazuje się, że 38\% ankietowanych wypijało $1-1,51$ wody, natomiast $35,4 \%$ 
respondentów wypijało 1,5-2 1. Mniej niż 11 wody dziennie piło $17,7 \%$ badanych. Najmniej liczna grupa osób $(8,9 \%)$ spośród ankietowanych, wypijała 2-2,5 1 wody w ciagu doby.

Po napoje energetyzujące kilka razy w miesiącu sięgało aż 30,4\% ankietowanych, natomiast kilka razy w tygodniu ponad 20\%. Nieliczna grupa ankietowanych $(5,1 \%)$ piła napoje energetyzujące codziennie. Blisko połowa ankietowanych (43\%) nie pijała ich w ogóle. W tabeli 2 zestawione zostały wyniki dotyczące częstotliwości picia napojów energetyzujących.

Tabela 2. Częstotliwość sięgania po napoje energetyzujące przez pracowników zmianowych

\begin{tabular}{|l|c|c|}
\hline Wyszczególnienie & Częstotliwość & Procent \\
\hline Codziennie & 4 & 5,1 \\
\hline $\begin{array}{l}\text { Kilka razy } \\
\text { w tygodniu }\end{array}$ & 17 & 21,5 \\
\hline $\begin{array}{l}\text { Kilka razy } \\
\text { w miesiącu }\end{array}$ & 24 & 30,4 \\
\hline W ogóle & 34 & 43,0 \\
\hline Ogółem & 79 & 100,0 \\
\hline
\end{tabular}

Źródło: opracowanie własne.

Z danych dotyczących spożycia kawy wynika, że większość pracowników sięgała najczęściej po 2 filiżanki kawy $(53,2 \%)$. Jedną filiżankę wypijało 15,2\% ankietowanych. Trzy lub więcej filiżanek kawy spożywało $15,1 \%$ osób, natomiast $16,5 \%$ badanych nie sięgał po kawę wcale. Badanie wykazało, iż wysoki odsetek ankietowanych $(44,3 \%)$ sięgał po soki, nektary i napoje gazowane typu cola.

Według wyników badań własnych większość osób $(68,4 \%)$ nie spożywała posiłków o regularnych porach. Tylko $31,6 \%$ ankietowanych zadeklarowało, że spożywa posiłki regularnie. Ponad połowa ankietowanych $(50,6 \%)$ spożywała tylko 2 posiłki dziennie, natomiast blisko $9 \%$ respondentów zadeklarowało, iż ze względu na system pracy konsumuje zazwyczaj tylko jeden posiłek. Cztery posiłki dziennie spożywało $10,1 \%$ respondentów, natomiast 5 i więcej posiłków dziennie spożywało tylko 1,3\% ankietowanych. Pozostała część respondentów $(29,1 \%)$ nie potrafiła określić częstotliwości konsumpcji posiłków.
W odpowiedzi na pytanie dotyczące ilości przekąsek, jaka zazwyczaj występowała pomiędzy posiłkami w pracy, wykazano, że pracownicy spożywają zdecydowanie więcej posiłków, niż podawali w odpowiedzi na wcześniejsze pytanie. Ponad połowa ankietowanych $(55,7 \%)$, oprócz posiłków wyszczególnionych zadeklarowała mianowicie, że konsumuje dwie dodatkowe przekąski dziennie. Ponad 1/5 respondentów $(21,5 \%)$ sięgała po jedną dodatkową przekąskę, natomiast „niekontrolowane” trzy przekąski występowały w diecie 15,2\% ankietowanych. Niższy odsetek ankietowanych $(3,8 \%)$ stanowili pracownicy, którzy dodatkowo dojadali 4 lub więcej razy podczas pobytu w pracy. Taki sam wynik $(3,8 \%)$ przedstawiał się u osób, które nie dojadały wcale.

$\mathrm{Na}$ podstawie wyników dotyczących rodzaju najczęściej wybieranych przekąsek podczas pobytu w pracy okazuje się, iż najwięcej ankietowanych (48\%) nie potrafiło określić, jakie przekąski preferują. Respondenci wybierali zarówno przekąski typu fast food, posiłki przygotowywane w miejscach, w których zazwyczaj się stołują, wysoko przetworzone przekąski zakupione w automatach lub pobliskich sklepach, owoce lub sałatki warzywne oraz samodzielnie przygotowane posiłki w domu. W drugiej kolejności pracownicy najczęściej wybierali kanapki lub wysoko przetworzone produkty, przy czym te pierwsze respondenci przyrządzali w domu lub wybierali takie, które były sprzedawane w miejscu pracy. Przekąskę w takiej postaci preferowało $21,5 \%$ badanych. Przekąski wyłącznie w postaci gotowych, wysoko przetworzonych produktów występowały w jadłospisie $10,1 \%$ respondentów. Dania typu fast food najczęściej wybierało 6,3\% ankietowanych. Posiłki zarówno typu fast food, jak i przygotowane w domu spożywało $2,5 \%$ ankietowanych, natomiast sałatki warzywne lub owoce konsumowało tylko 5,1\% respondentów. Spośród wszystkich pracowników objętych badaniem po same owoce sięgało wyłącznie $2,5 \%$.

Następne pytanie dotyczyło przerwy między posiłkami, jakie występowały zazwyczaj w jadłospisie respondentów podczas zmian dziennych. Ponad połowa ankietowanych (57\%) spożywała posiłek, co 3-4 godziny. Posiłki, co 5 godzin konsumowane były aż przez 31,6\% pracowników. Blisko $8 \%$ respondentów zadeklarowało, 
że miewa zdecydowanie dłuższe przerwy, trwające nawet ponad 5 godzin, natomiast po posiłek co 2 godziny sięgało $3,8 \%$ badanych osób. Zestawiając procentowy udział pracowników, w stosunku do długości przerwy, jaka występowała zazwyczaj podczas zmiany dziennej i nocnej, można zauważyć duże zróżnicowanie. Najwięcej pracowników $(73,4 \%)$ podczas zmiany nocnej robiło przerwy wynoszące 3-4 godziny. Blisko
14\% ankietowanych nie spożywało żadnych posiłków w nocy. U blisko $9 \%$ respondentów przerwy trwały powyżej 5 godzin. Mniej niż dwugodzinne przerwy podczas zmian nocnych, podobnie jak podczas zmian dziennych zadeklarowało 3,8\% ankietowanych.

Tabela 1 obrazuje procentowe zestawienie długości przerw między posiłkami podczas zmian nocnych i dziennych.

Tabela 1. Procentowe zestawienie pracowników odnoszące się do długości przerwy pomiędzy positkami, jakie najczęściej występowały podczas zmian nocnych i dziennych

\begin{tabular}{|l|c|c|}
\hline \multicolumn{1}{|c|}{$\begin{array}{c}\text { Wyszczególnienie długości przerw } \\
\text { pomiędzy positkami }\end{array}$} & $\begin{array}{c}\text { Procent pracowników } \\
\text { (zmiany dzienne) }\end{array}$ & $\begin{array}{c}\text { Procent pracowników } \\
\text { (zmiany nocne) }\end{array}$ \\
\hline 5 i więcej godzin & 7,6 & 8,9 \\
\hline Od 3-4 godzin & 88,6 & 73,4 \\
\hline Mniej niż 2 godziny & 3,8 & 3,8 \\
\hline Nie spożywam posiłków podczas pobytu w pracy & - & 14,0 \\
\hline
\end{tabular}

Źródło: opracowanie własne.

W badaniu zwrócono uwagę na ilość słodyczy i wysokoprzetworzonych przekąsek, jaką spożywali pracownicy. Wyszczególnione zostały batony, cukierki oraz słone przekąski, takie, jak: paluszki, orzeszki solone, krakersy czy chipsy. Najwyższy odsetek ankietowanych $(36,7 \%)$ stanowili pracownicy, którzy spożywali wspomniane produkty kilka razy w tygodniu. Podobne wartości wykazano u osób spożywających je kilka razy w miesiącu (34,2\%). Codziennie po wysoko przetworzone i słodkie przekąski sięgało aż 21,5\% ankietowanych. Tylko w diecie 7,6\% respondentów wyżej wymienione produkty nie znajdowały się w ogóle.

Zaledwie $26,6 \%$ osób sięgało po owoce i warzywa codziennie, natomiast $13,9 \%$ respondentów spożywała je tylko kilka razy w miesiącu. Najniższy odsetek pracowników $(2,5 \%)$ stanowiły osoby, które nie sięgały po wspomniane produkty wcale. Analizując wyniki dotyczące częstości występowania w diecie nasion roślin strączkowych, można stwierdzić, że największy odsetek badanych $(49,4 \%)$ spożywał je kilka razy w miesiącu. Blisko 1/3 osób (32,9\%) miało w zwyczaju spożywać je kilka razy w tygodniu, natomiast $13,9 \%$ osób w ogóle nie wprowadzało ich do diety. Okazuje się, że w jadłospisie tylko 3,8\% ankietowanych znajdowały sie one codziennie. Analizując deklaracje respondentów dotyczące spożycia śniadania niezależnie od charakteru zmiany pracy, widzimy, że większość ankietowanych (62\%) konsumowała pierwszy posiłek bezpośrednio po przebudzeniu. Około 1/4 pracowników objętych badaniem $(24,1 \%)$ nie spożywało śniadań wcale. Najniższy odsetek osób $(13,9 \%)$ stanowili pracownicy, którzy nie przywiązywali uwagi do godziny pierwszego posiłku.

W pracy wyszczególniono również występowanie posiłku obiadowego. Zdecydowana większość, bo aż $69,6 \%$ ankietowanych, spożywała obiad. Blisko 10,1\% respondentów nie konsumowało obiadu w ogóle, natomiast 20,3\% ankietowanych sporadycznie spożywało posiłek główny. Kolejnym poruszonym aspektem była forma konsumowanych posiłków podczas pobytu w pracy. Okazuje się, że najwięcej respondentów (38\%) spożywało głównie posiłki, które przyrządzili w domu. Blisko 1/4 osób $(24,1 \%)$ stwierdziła, iż stołuje się $\mathrm{w}$ barach lub restauracjach, ulokowanych nieopodal miejsca pracy. Tylko $10 \%$ respondentów korzystało ze stołówek, które znajdowały się w miejscu pracy. Blisko $28 \%$ stołowało się w różnych miejscach, a także spożywało posiłki przygotowane w domu.

Biorąc pod uwagę rodzaj mięsa, jaki konsumowany był najczęściej, stwierdzono, że blisko połowa ankietowanych $(48,1 \%)$ preferowała mięso czerwone. Po wieprzowinę 
najchętniej sięgało $17,7 \%$ respondentów, po wołowinę $11,4 \%$, natomiast cielęcinę wybierało $19 \%$ ankietowanych. Pozostała część pracowników zadeklarowała, że najczęściej sięga po mięso drobiowe. Żaden z pracowników objętych badaniem nie preferował dziczyzny ani jagnięciny. Pozostali uczestnicy zadeklarowali, iż są wegetarianami. Kolejne pytanie dotyczyło częstości spożywania wysoko przetworzonego mięsa (wędliny, wyroby wędliniarskie czy produkty konserwowane). Większość ankietowanych $(50,6 \%)$ spożywało wspomniane produkty kilka razy w tygodniu. Produkty takie codziennie występowały w diecie $26,6 \%$ badanych. Blisko $1 / 5$ respondentów $(19,0 \%)$ spożywała wymienione produkty kilka razy w miesiącu.
Wyniki dotyczące częstości spożywania ryb obrazują, że około $57 \%$ ankietowanych spożywało je kilka razy w miesiacu lub nawet rzadziej. Zaledwie 36,7\% osób wprowadzało ryby do jadłospisu kilka razy w tygodniu, natomiast $6,3 \%$ respondentów nie spożywało ryb w ogóle.

Praca w systemie zmianowym ma negatywny wpływ na wiele aspektów życia, w tym również na stan zdrowia. W tabeli 3 przedstawiono wyniki dotyczace występowania wśród respondentów wybranych schorzeń (zaliczanych do niezakaźnych chorób cywilizacyjnych). W badaniu wzięto pod uwagę, m.in. problemy żołądkowo-jelitowe, zaburzoną gospodarkę węglowodanową, choroby sercowo-naczyniowe oraz nadciśnienie tętnicze.

Tabela 3. Wybrane, najczęściej diagnozowane schorzenia, wśród osób pracujących w systemie zmianowym

\begin{tabular}{|l|c|c|}
\hline \multicolumn{1}{|c|}{ Wyszczególnienie } & Częstotliwość & Procent \\
\hline Problemy żołądkowo-jelitowe & 13 & 16,4 \\
\hline Problemy z poziomem cukru we krwi & 1 & 1,3 \\
\hline Choroby sercowo-naczyniowe & 6 & 7,6 \\
\hline Nadciśnienie tętnicze & 10 & 12,7 \\
\hline Brak schorzeń & 49 & 62,0 \\
\hline Ogółem & 79 & 100,0 \\
\hline
\end{tabular}

Źródło: opracowanie własne.

Stwierdzono, że ponad połowa ankietowanych (62\%) nie cierpiała na żadne z wymienionych schorzeń. Ponad $15 \%$ pracowników zadeklarowało, iż dokuczają im problemy związane z wypróżnieniami, natomiast problemy $\mathrm{z}$ gospodarką węglowodanową występowały u 1,3\% ankietowanych. Szczególnie zauważalna była wysoka zapadalność na choroby o podłożu sercowo-naczyniowym $(20,3 \%)$ oraz schorzenia żołądkowo-jelitowe $(16,4 \%)$. Według autorskiego badania najczęstszymi dolegliwościami deklarowanymi przez pracowników były zaparcia $(22,8 \%)$, biegunka $(8,9 \%)$ i wzdeccia $(8,8 \%)$.

Kolejne pytanie dotyczyło subiektywnego odczucia głodu podczas zmian nocnych. Stwierdzono, że blisko połowa pracowników $(45,6 \%)$ spożywała posiłki w pracy dopiero wtedy, gdy odczuwała silny głód. Okazuje się, że $43 \%$ respondentów starało się sięgać po posiłek przygotowany wcześniej, aby zapobiec pojawieniu się takiego odczucia. $\mathrm{Z}$ kolei $6,3 \%$ ankietowanych, niezależnie od towarzyszącego im głodu, nie konsumowało posiłku w pracy, ani po powrocie do domu. Najniższy odsetek badanych osób $(5,1 \%)$ stanowili pracownicy, którzy rezygnowali z posiłku w pracy, pomimo doskwierającego im głodu.

Kolejna kwestia dotyczyła dolegliwości związanych z charakterem pracy. Zmęczenie wraz z bezsennością oraz nerwowością występowały u 3,8\% ankietowanych. Zmęczenie, bezsenność, nerwowość, ograniczona zdolność do wysiłku wraz z utratą apetytu stanowily problem u $13 \%$ ankietowanych. Na zmęczenie wraz z nerwowością cierpiał niski odsetek osób (2,5\%). Bezsenność występowała u 15,1\% ankietowanych, natomiast na nerwowość cierpiało $12,7 \%$ 
osób. Ograniczoną zdolność do wysiłku odczuwało 22,8\% respondentów. Ograniczona zdolność do wysiłku wraz z utrata apetytu występowała u 2,5\% osób. Tylko utratę apetytu zadeklarowało 7,6\% badanych, natomiast utrata apetytu wraz z nerwowością przejawiała się u 2,5\% ankietowanych.

\section{Wnioski}

Błędem żywieniowym mogącym pogłębiać zmęczenie i zmniejszać tym samym efektywność pracowników jest brak regularności w dostarczaniu wody. Odpowiednie nawodnienie zawsze będzie nierozłącznym elementem zbilansowanej diety. Pracownicy zmianowi są szczególnie narażeni na odwodnienie i związaną $\mathrm{z}$ tym zmniejszoną wydolność organizmu (Gifkins i Loudoun, 2018). Respondenci wyrażali niezdolność do picia wystarczającej ilości płynów w pracy, tym samym zaobserwowana została zbyt niska ilość konsumowanej wody.

W celu złagodzenia odczucia zmęczenia pracownicy sięgali natomiast po napoje energetyzujące i kawę. Umiarkowane spożycie kawy wydaje się lepszym wyborem niż spożycie napojów energetyzujących. W przeglądzie badań od 1966 do 2002 r. nie odnaleziono dowodów na to, że picie kawy może negatywnie wpływać na nawodnienie organizmu. Ponadto publikowane dane wskazują, że kawa może być pomocna w obniżaniu ciśnienia tętniczego, dzięki zawartości kwasu chlorogenowego (Loader $\mathrm{i}$ in., 2017).

$\mathrm{Na}$ podstawie badań własnych stwierdzono, że regularność posiłków była ściśle zależna od charakteru pracy. Podczas zmiany dziennej pracownicy odżywiali się regularniej niż w godzinach nocnych, bowiem aż $57 \%$ badanych spożywało posiłki, co 3-4 godziny. W ciaggu nocy odsetek ten był zdecydowanie niższy $(35,4 \%)$. Zadowalający był fakt, iż śniadanie, niezależnie od charakteru pracy, spożywała większość ankietowanych.

Wysoki odsetek ankietowanych stanowili pracownicy, którzy spożywali głównie produkty wysoko przetworzone, takie jak słodkie i słone przekąski. Codziennie po te produkty sięgało aż $21,5 \%$ ankietowanych. Najwięcej respondentów (38\%) spożywało głównie posiłki, które przyrządzili w domu. Blisko aż $25 \%$ respondentów stołowało się jednak wyłącznie w barach lub restaura- cjach. Posiłki pracowników były zazwyczaj monotonne, spożywane w pośpiechu, bez zwracania uwagi na ich jakość. Takie błędy żywieniowe popełniane były najczęściej przez młodych pracowników i mogły wynikać z braku dbałości o jakość odżywiania się, bądź niewystarczającej ilości czasu na samodzielne przygotowywanie posiłków.

Pracownicy zmianowi są szczególnie narażeni na zwiększone ryzyko różnorodnych zaburzeń. Najczęściej wymienianymi w literaturze są, m.in. nadmierna masa ciała, cukrzyca typu 2, choroby sercowo naczyniowe, zaburzenia snu, zaburzenia trawienia czy niedobory witamin. Wśród pracowników zmianowych można zauważyć ponadto częste występowanie dolegliwości ze strony układu pokarmowego. Zjawisko to może wynikać z dużych przerw, jakie występują między posiłkami. Niesprzyjającym zjawiskiem, zwiększającym ryzyko chorób sercowo-naczyniowych był fakt, że wysoki odsetek ankietowanych (20\%), stanowiły osoby, które spożywały posiłki przygotowywane przez bary typu fast food. Należy zaznaczyć, że podstawową techniką obróbki kulinarnej, wykorzystywaną do przygotowywania posiłków w barach fast food jest smażenie zanurzeniowe $\mathrm{z}$ użyciem nieodpowiedniego tłuszczu roślinnego. Ponadto posiłki są $\mathrm{z}$ reguły przyrządzane z użyciem dużej ilości soli, bądź przypraw z dodatkiem glutaminianu sodu. Konsekwencją tego jest zwiększone ryzyko nadciśnienia tętniczego.

$\mathrm{Z}$ nadciśnieniem tętniczym borykało się $12,7 \%$ ankietowanych. Na uwagę zasługuje badanie opublikowane w The New England of Medicine, w którym zmniejszenie podaży soli poprzez zastosowanie diety DASH doprowadziło do obniżenia średniego skurczowego ciśnienia krwi o 7,1 mm Hg u osób niemających nadciśnienia i o $11,5 \mathrm{~mm} \mathrm{Hg}$ u uczestników ze zdiagnozowanym nadciśnieniem tętniczym (Frank i Laura, 2001). Ponadto dodatkowym czynnikiem predysponującym do nadciśnienia u pracowników zmianowych jest konieczność podjęcia aktywności nocą, w czasie niezgodnym z rytmem dobowym organizmu.

W badaniach własnych wykazano wysokie spożycie przetworzonych produktów mięsnych. Warto zaznaczyć, że zbyt wysoka ilość przetworzonego mięsa stanowi kolejny czynnik zwiększający ryzyko chorób sercowo-naczyniowych i nowotworowych (World Health Organization, 2018). Biorąc 
pod uwagę gatunek mięsa, jaki wybierany był najczęściej przez uczestników badania, blisko połowa $(48,1 \%)$ preferowała mięso czerwone. Zjawisko to jest niepokojace, gdyż według ekspertów WHO ryzyko wystąpienia raka prostaty może się zwiększać o 17\%, wraz z każdą kolejną 100 gramową porcją czerwonego mięsa konsumowaną w ciągu dnia (Raphaëlle, Fabrice i Corpet, 2008). Ponadto większość ankietowanych $(50,6 \%)$ spożywała mięso czerwone aż kilka razy w tygodniu w postaci wędlin, bądź wysoko przetworzonych produktów mięsnych. Prospektywne badanie kohortowe wśród japońskich pracowników zmianowych płci męskiej ujawniło zwiększoną zachorowalność na raka prostaty (Kubo $\mathrm{i}$ in., 2006). U mężczyzn wykazano również słabsze parametry nasienia i zmniejszoną płodność (Lipshultz i in., 2018).

Dieta respondentów charakteryzowała się niską zawartością kwasu dokozaheksaenowego (DHA) i kwasu eikozapentaenowego (EPA). W jadłospisie pracowników znajdowało się przede wszystkim zbyt mało ryb, obfitujących w EPA i DHA. Ponad $6 \%$ osób objętych autorskim badaniem nie spożywało ryb w ogóle. Z kolei wyniki metaanalizy z udziałem 200 tys. osób wykazały, że wystarczy wprowadzić, co najmniej 1 porcję raz w miesiącu ryb do diety, aby istotnie obniżyć ryzyko wystąpienia udaru czy choroby niedokrwiennej serca (He i in., 2004).

W badaniach własnych wysoki odsetek respondentów $(16,4 \%)$ zadeklarował, że miewa problemy żołądkowo-jelitowe. Problemami ze strony układu pokarmowego były zaparcia, biegunka i wzdęcia. Wyniki badania autorskiego potwierdzają dane z 2017 roku (Lim, 2017). U 20\% pracowników, którzy doświadczyli 24-godzinnej zmiany w ciagu ostatnich 6 miesięcy, stwierdzono zaburzenia żołądkowo-jelitowe.

W jadłospisie respondentów wykazano zbyt niskie spożycie produktów obfitujących w błonnik pokarmowy. W głównej mierze zjawisko to było spowodowane niską podażą warzyw i owoców. Większość ankietowanych $(57 \%)$ spożywała wspomniane produkty tylko kilka razy w tygodniu. Stwierdzono, że zbyt niska podaż włókna roślinnego może doprowadzać do dysbiozy mikroflory jelitowej. Zjawisko to predysponuje do rozwoju chorób układu pokarmowego, spośród których można wyróżnić schorzenia, takie jak zespół jelita drażliwego i nieswoiste zapalne choroby jelit (Dudzińska, 2016). Objawy te mogą być również spowodowane różnicami w procesie wchłaniania, bądź trawienia pokarmów w godzinach nocnych. Takie zjawisko predysponuje do rozwoju dolegliwości, takich jak: zmniejszenie apetytu, cofanie się treści pokarmowej, wzdęcia, nieregularność wypróżnień. Według badań obserwacyjnych zaburzony rytm snu i czuwania jest również czynnikiem zwiększającym ryzyko rozwoju lub zaostrzenia wspomnianych schorzeń $\mathrm{i}$ ich następstw (Swanson, Burgess i Keshavarzian, 2011).

Rozpatrując zachowania żywieniowe ankietowanych, warto zwrócić uwagę na wiek respondentów. Według ekspertów WHO proces starzenia się organizmu obniża zdolność do adaptacji, w związku $\mathrm{z}$ czym praca $\mathrm{w}$ trybie trzyzmianowym jest niezalecana dla pracownika powyżej 45. roku życia (Zużewicz i Konarska, 2004). Największą część grupy respondentów w badaniach własnych stanowiły osoby $(62 \%)$ w wieku oscylujaccym w granicach 26-40 lat. Ponad $15 \%$ ankietowanych stanowily osoby wieku 41-50 lat. Warto zaznaczyć również, że ponad połowa $(50,6 \%)$ badanych miała wykształcenie średnie, co mogło być przyczyną braku wiedzy żywieniowej.

\section{Podsumowanie}

Stwierdzony w badaniach własnych sposób odżywiania się osób pracujących na zmiany odbiegał od racjonalnych zasad żywienia. Powodem tego może być niedostateczna wiedza oraz mała świadomość respondentów $\mathrm{w}$ zakresie podstaw nauki o żywności i żywieniu. Pracownicy zmianowi odczuwali szereg dolegliwości, związanych z pogarszającym się szeroko rozumianym stanem zdrowia. Ponadto wysoki odsetek badanych deklarował, że cierpi na bezsenność, rozdrażnienie czy nerwowość. Reasumując, można stwierdzić, że wśród respondentów wiedza na temat właściwego sposobu żywienia była zbyt niska. Ankietowani popełniali podstawowe błędy, dotyczące między innymi regularności i ilości spożywanych oraz ilości wypijanych płynów. Takie postępowanie może skutkować rozwojem nadwagi, otyłości oraz innych chorób dietozależnych.

W literaturze znajduje się zbyt mało informacji opartych na EBM (ang. evidence 
based medicine), dotyczących odżywiania o różnych porach dnia i nocy. Według dyrektywy Parlamentu Europejskiego i Rady Europy (2003/88/WE), poruszającej aspekty pracy w systemie zmianowym, pracodawca ma obowiązek zagwarantować, jak najlepsze warunki pracy. Wymagania zawarte w rozporządzeniu mają głównie na celu zwiększyć komfort pracy i tym samym umożliwić pracownikom utrzymanie przez jak najdłuższy czas dobrego stanu zdrowia (Gersdorf i in., 2004). Liczne dane literaturowe potwierdzają, że lepszy stan zdrowia pracowników ściśle koreluje ze zwiększoną efektywnością i ich wydolnością w pracy. W celu zwiększenia wiedzy i świadomości osób pracujących na zmiany dobrym przedsięwzięciem byłoby wprowadzenie kampanii i programów edukacyjnych zarówno dla pracowników zmianowych, jak i ich przełożonych.

\section{Bibliografia}

Bilski, B., Perz, S. i Perz, K. (2005). Czy egzogenna melatonina może być skuteczna $\mathrm{w}$ profilaktyce i leczeniu zaburzeń związanych z pracą zmianową i nocną? Medycyna Pracy, 56(3), 257-261.

Bøggild, H. i Knutsson, A. (1999). Shift work, risk factors and cardiovascular disease. Scand $J$ Work Environ Health, 2(2), 85-99, http://dx.doi. org/10.5271/sjweh.410

Brzęczek, M., Słonka, K. i Hyla-Klekot, L. (2016). Melatonina - hormon o plejotropowym działaniu. Pediatria i Medycyna Rodzinna, 12(2), 127-133.

Dudzińska, E. (2016). Wpływ mikroflory jelitowej na rozwój zespołu jelita drażliwego. Medycyna Środowiskowa, 19(3), 70-76.

Frank, M. i Laura, P. (2001). Effects on Blood Pressure of Reduced Dietary Sodium and the Dietary Approaches to Stop Hypertension (DASH). Diet $N$ Engl J Med., 4(1), 3-10, http://dx.doi.org/10.1056/ NEJM200101043440101.

Gersdorf, M., Rączka, K., Skoczyński, J. i Salwa, J. (2004). Praca w porze nocnej. Kodeks pracy. Komentarz. Warszawa: LexisNexis.

Gifkins, A., Johnston, J. i Loudoun, R. (2018). The impact of shift work on eating patterns and selfcare strategies utilised by experienced and inexperienced nurses. The Journal of Biological and Medical Rhythm Research, 96(12), 811-820, doi:10.1080/074 20528.2018.1466790

He, K, Song, Y., Daviglus, M.L., Liu K., Van Horn, L. i Dyer, A.R. (2004). Fish consumption and incidence of stroke: a meta-analysis of cohort studies. Stroke, 35(7), 538-542, http://dx.doi. org/10.1161/01.STR.0000130856.31468.47
Hittl, J., Gillespi, S., Zizi, F., Pandi-Perumal, S.R., Myers, A.K., Auguste, E., Jean-Louis, G. i McFarlane, S.I. (2018). Identifying shift worker chronotype: implications for health.). Industrial Health, 3, http://dx.doi.org/10.2486/indhealth.2018-0018

Hulsegge, G., Picavet, J., Van der Beek, J., Verschuren, W. i Twisk, J. (2018). Shift work, chronotype and the risk of cardiometabolic risk factors. Eur J. Public Health, http://dx.doi.org/10.1093/eurpub/ cky092.

Jehan, S., Zizi Ferdinand, R., Pandi-Perumal, S.K., Myers, A., Auguste, E., Jean-Louis, G. i McFarlane, S. (2017). Shift Work and Sleep: Medical Implications and Management. Sleep Med Disord. 1(2), 1-14, doi.org/10.1136/bmjopen-2017-019098

Kawachi, I., Colditz, G.A., Stamfer, M.J., Willett, W.C. i Manson, J.E. (1996). Prospective study of shift work and risk of coronary heart disease in women. Circulation, 92(11), 3178-3182.

Knauth, P. i Hornberge, S. (2003). Preventive and compensatory measures for shift workers. Occupational Medicine, 53, 109-116, http://dx.doi. org/10.1093/occmed/kqg049

Kubo, T., Ozasa, K., Mikami, K., Wakai, Ki i Fujino, Y. (2006). Prospective Cohort Study of the Risk of Prostate Cancer among Rotating-Shift Workers: Findings from the Japan Collaborative Cohort Study. American Journal of Epidemiology, 164(6), 549-555, http://dx.doi.org/10.1093/aje/kwj232

Kwarecki, K. i Zużewicz, K. (2002). Charakterystyka snu i dobowego wzoru aktywności lokomotorycznej u pracowników zmian nocnych. Medycyna Pracy, 53(1), 79-84.

Lavie, P. (1997). Melatonin: role in gating nocturnal rise in sleep propensity. $J$. Biol. Rhythms. 12(6), 657-665, http://dx.doi. org/10.1177/074873049701200622

Lemmer, B. i Oster, H. (2018). The Role of Circadian Rhythms in the Hypertension of Diabetes Mellitus and the Metabolic Syndrome. Curr Hypertens Rep., 20(5), 43, http://dx.doi.org/10.1007/ s11906-018-0843-5

Lim, S.K., Yoo, S.J., Koo, D.L., Park, C.A., Ryu, H.J. i Jung, Y.J. (2017). Stress and sleep quality in doctors working on-call shifts are associated with functional gastrointestinal disorders. World J Gastroenterol., 23(18), 3330-3337, http://dx.doi. org/10.3748/wjg.v23.i18.3330

Lipshultz, L.I., Pastuszak, A.W., Deng, N., Kohn, T.P. (2018). The Relationship Between Shift Work and Men's Health. Sex Med Rev., 6(3), 446-456, http:// dx.doi.org/10.1016/j.sxmr.2017.11.009

Loader, T.B., Taylor, C.G., Zahradka, P. i Jones, P.J. (2017). Chlorogenic acid from coffee beans: evaluating the evidence for a blood pressure-regulating health claim. Nutr Rev. 75(2), 114-133, http://dx.doi. org/10.1093/nutrit/nuw057 
Maughan, R.J. i Griffin, J. (2003). Caffeine ingestion and fluid balance: a review. J Hum Nutr Diet., 16(6), 411-420.

Pawlak, J. i Pawlak, B. (2013). Praca zmianowa a powstawanie chorób układu sercowo naczyniowego w kontekście regulacji normatywnej. Hygeia Public Health., 48(1), 6-9.

Ramin, C., Devore, E.E., Wang, W., Pierre-Paul, J., Węgrzyn, L.R. i Schernhammer, E.S. (2015). Night shift work at specific age ranges and chronic disease risk factors. Occup Environ Med., 72(2), 100-107, http://dx.doi.org/10.1136/oemed-2014-102292

Raphaëlle, L., Fabrice, P. i Corpet, D.E. (2008). Processed meat and colorectal cancer: a review of epidemiologic and experimental evidence. Nutr Cancer., 60(2), 131-144, http://dx.doi. org/10.1080/01635580701684872

Saksvik, I.B., Bjorvatn, B., Hetland, H., Sandal, G.M. i Pallesen, S. (2011). Individual differencesintolerance to shift work. A systematic review. Sleep Med Rev. 15(4), 221-235, http://10.1016/j. smrv.2010.07.002

Strajewski, P.J., Kuczaj, A., Domal-Kwiatkowska, D. i Mazurek, U. (2016). Wpływ pracy nocnej i zmianowej na zdrowie pracowników. Przegląd Lekarski, 73(7), 513-514.

Swanson, G.R., Burgess, H.J. i Keshavarzian, A. (2011). Sleep disturbances and inflammatory bowel disease: a potential trigger for disease flare.
Expert Rev Clin Immunol. 7(1), 29-36, http://dx.doi. org/10.1586/eci.10.83

Van Wormer, J., Boucher, J.L. i Sidebottom, A.C. (2015). Two-year impact of lifestyle changes on workplace productivity loss in the Heart of New Ulm Project. Occup Environ Med., 72, 460-462.

Villosio, C., Di Pierro, D, Giordanengo, A., Pasqua, P. i Richiard, M. (2008). LABORatorio Riccardo Revelli (LABOR) Collegio Carlo Alberto. Centre for Employment Studies. Working conditions of an ageing workforce. Dublin: Centre for Employment Studies. European Foundation for the Improvement of Living and Working Conditions.

Wołyniec, W., Kurlapski, M., Januszczyk, J. i Renke, M. (2015). Cukrzyca w społeczeństwie 24/7. Związek między pracą zmianową a zaburzeniami metabolicznymi. Diabetologia Kliniczna, 4(1), 22-28, http://dx.doi.org/10.5603/DK.2015.0004

World Health Organization. (2014). Italy: World Health Organization. Basic documents. Forty-eighth edition.

World Health Organization. (2018). France: IARC Library Cataloguing in Publication Data Red Meat and Processed Meat. Editors IARC Working Group on the Evaluation of Carcinogenic Risk to Humans. International Agency for Research on Cancer.

Zużewicz, K., Konarska, M. (2004). Changes in age-related tolerance of physical and mental shift work. Bezpieczeństwo Pracy, 7(8), 28-30. 